\title{
Comparison of reproduction and carcass traits in light type of ducks of four conservative flocks over eight generations
}

\begin{abstract}
Ducks of four conservative flocks: Khaki Campbell (Kh1), Orpington (01), crossbreds of those two breeds (Kh0) and Miniducks (K2) being kept without selection over 8 generations were used for analysis. The mean values of reproductive and carcass traits were determined and illustrated by linear regression equations. In the first year of study a significant differentiation was noted among flocks in: number of eggs, from 101 (K2) to 156 (Kh1); egg weight, from $70(\mathrm{~K} 2)$ to $75 \mathrm{~g}(\mathrm{Kh} 0)$ and hatchability from fertilized eggs, from $62(\mathrm{Kh} 0)$ to $72 \%$ (K2). Upward time trends in egg weight and hatchability from fertilized eggs were noted in all flocks of birds, whereas in egg number in Kh1, 01 and K2 flock; and in egg fertilization in Kh1 and Kh0 flocks. In the second year a lower egg number and egg weight were found, as well as lower egg fertilization and hatchability. Differentiation in meatiness mean values between flocks was found over 8 generations of both sexes at 7 weeks of age in body weight and in breast and leg muscles yield in the carcass. Upward time trends in leg muscle yield and skin with subcutaneous fat content in the carcass were noted in all flocks of ducks of both sexes while in body weight at 7 weeks of age in the females of Kh1 and K2 flocks. Contrary, downward time trends in the body weight at 3. week of age and in breast muscle yield at 7 . week of age were found in birds of both sexes and all conservative flocks.
\end{abstract}

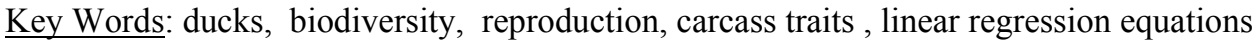

\section{Zusammenfassung}

Titel der Arbeit: Vergleich von Reproduktions- und Schlachtkörpermerkmalen zwischen 4 genetisch unterschiedlichen Entenpopulationen

Vier genetisch unterschiedliche Entenpopulationen Khaki Campbell (Kh1), Orpington (01), Hybriden dieser Rassen (Kh0) und Minienten (K2) wurden über acht Generationen in vergleichbaren Fütterungs- und Umweltbedingungen ohne Selektion gehalten. Es wurden Mittelwerte von Reproduktions- und Schlachtkörpermerkmalen bestimmt sowie lineare Regressionsgleichungen berechnet. Im ersten Jahr konnten signifikante Unterschiede zwischen den Tiergruppen ermittelt werden. Sie betrugen bei der Eizahl 101 ((K1) bis 156 (Kh1), dem Eigewicht 70 (K2) bis $75 \mathrm{~g} \mathrm{Kh01)}$ und dem Schlupf der befruchteten Eier 62 (Kh0) bis $72 \%$ (K2). Im zweiten Jahr wurde eine Verringerung in der Anzahl und im Gewicht der Eier beobachtet. Im ersten Jahr sind in allen Gruppen wachsende Zeittrends im Eigewicht und bei den Schlupfprozenten, bezogen auf die befruchteten Eier, ermittelt worden. Bei den K1, 01 sowie K2 Gruppen trat diese Tendenz bei der Eizahl und bei den K1 sowie Kh0 Gruppen bei der Befruchtung der Eier auf. Mittelwertdifferenzen im Merkmal Fleischanteil wurden beim Körpergewicht der Tiere beider Geschlechter und beim Anteil von Brust- und Schenkelmuskulatur am Schlachtkörper in der siebenten Woche über acht Generationen festgestellt In allen Tiergruppen und bei beiden Geschlechtern konnten Zuwächse im Brust- und Schenkelanteil sowie im Haut- und Hautfettanteil des Schlachtkörpers nachgewiesen werden. Bei den weiblichen Tieren der Kh1 sowie K2 Gruppe betraf das in der siebenten Woche auch das Körpergewicht. Abnehmende Zeittrends im Körpergewicht sowie Brustfleischanteil wurden andererseits in der dritten bzw. siebenten Lebenswoche bei beiden Geschlechtern aller Entengruppen festgestellt.

Schlüsselwörter: Enten, Fortpflanzung, Biodivergenz, Schlachtmerkmale, lineare Regression

\section{Introduction}

Conservation of genetically different animals, among them birds, existing in small populations and threatened with extinction is required for economic, scientific, cultural 
and historical reasons (WORLD WATCH LIST FOR DOMESTIC ANIMAL DIVERSITY - FAO, 2000). From the point of view of breeding maintaining genetically diversified conservative flocks of birds is necessary to give rise to genetic variation in the selected populations. Such flocks are being used in the duck to create new breeding or experimental strains, synthetic groups as well as to search for heterosis effects in commercial crossbreds (KSIAZŻKIEWICZ, 1995). The maintenance programme of conservative flocks of birds specifies that their performance traits should be evaluated on a regular basis. Among conservative flocks of duck, differentiated values of performance traits, investigated over one or six generations were found in the studies carried out so far (KSIAZŻKIEWICZ, 1995; 1997).

Ducks kept in small populations are particularly susceptible to the intense effects of inbreeding and genetic drift. For this reason the investigation of changing trends in the non-selected traits over many generations is particularly important. This can be achieved by testing birds in comparable environmental and feeding conditions using the same experimental procedures.

The purpose of the study was to compare reproductive and meatiness traits in four conservative flocks of light type ducks, and to illustrate the trends in the performance traits over eight generations by linear regression equations.

\section{Material and Methods}

Ducks from four conservative flocks maintained in situ were used as experimental material:

- Khaki Campbell (Kh1) ducks originating from the parent stock imported from France in 1971;

- Orpington ducks (01) of yellow-brown variety, from the breeding stock imported from France in 1971;

- $\quad$ crossbred ducks (Kh0) being a cross of 50\% Kh1 and 50\% 01;

- Mini-ducks (K2), bred from wild duck (Anas platyrhynchos L.) and Pekin duck (KSIĄŻKIEWICZ, 2002; WORLD WATCH LIST - FAO, 2000).

Birds of the Kh1, 01 and Kh0 flocks are characterized by brown, and those of the K2 flock by white feathers.

All birds were maintained under the same testing conditions during 16 years period. The evaluation of the reproductive traits was conducted over 8 generations in the first and second year of laying performance. Reproduction of birds was carried out every second year and the individuals used in mating were taken at random without selection for performance traits. Carcass meatiness was evaluated always in the progeny from parents being in the second year of reproductive performance. That procedure resulted from the adopted programme of bird conservation and the methods of maintaining genetic resources of waterfowl (KSIĄŻKIEWICZ, 2002).

In each conservative flock and duck generation a uniform system of 4 subgroups was used. This system allows for male rotations and protects the flock against inbreeding effect. In the first year of the performance, each flock comprised at least 20 males and 80 females, with up to 40 males and 160 females in the K2 flock (Table 1). In the second year, the number of birds tested diminished due to bird mortality and culling for health reasons. The formula of WRIGHT (1931) was used to calculate the effective size of the population $\left(\mathrm{N}_{\mathrm{e}}\right)$, i.e. the rate of gene elimination as a result of random 
genetic drift and the increase in flock homozygosity $(\Delta \mathrm{F})$ which is inversely proportional to the effective size of the population according to the formulas:

$$
\begin{gathered}
N_{e}=\frac{4 N_{m} \times N_{f}}{N_{m}+N_{f}} \\
F_{x}=\frac{1}{2 N_{e}}
\end{gathered}
$$

where : $\mathrm{N}_{\mathrm{m}}=$ number of males

$\mathrm{N}_{\mathrm{f}}=$ number of females

Table 1

Actual and effective size of the population $\left(\mathrm{N}_{\mathrm{e}}\right)$ and the increase in homozygosity $(\Delta \mathrm{F})$ in ducks from conservative flocks (Aktuelle und effective Größe der Population und Homozygotiezuwachs der Entenpopulation)

\begin{tabular}{ccccc}
\hline $\begin{array}{c}\text { Flock } \\
\text { symbol }\end{array}$ & $\begin{array}{c}\text { Actual size of the population } \\
\hat{n}\end{array}$ & 0 & $\begin{array}{c}\text { Effective size of } \\
\text { the population }\left(\mathrm{N}_{\mathrm{e}}\right)\end{array}$ & $\begin{array}{c}\text { Increase in } \\
\text { homozygosity }(\Delta \mathrm{F})\end{array}$ \\
\hline $\mathrm{Kh} 1, \mathrm{O} 1, \mathrm{KhO}$ & 20 & 80 & 64 & 0.78 \\
$\mathrm{~K} 2$ & 40 & 160 & 128 & 0.39 \\
\hline
\end{tabular}

According to WORLD WATCH LIST of FAO classification (2000) Kh1, 01 and KhO flocks with females number less than 100 are threatened with extinction. This is accompanied by increase homozygosity (Table 1).

The number of ducks of the same sex evaluated for body weight in the third and seventh week of age ranged from 50 to 200 individuals in each flock and generation. In the seventh week of age, from each flock 5 males and 5 females having body weight close to the arithmetic mean of body weight of males and females in a particular flock were taken for carcass dissection.

The housing system in particular years of the study was similar and in accordance with the rules of raising and keeping parent stock of ducks (KSIAZŻKIEWICZ, 2002). During the testing period, the birds from all conservative flocks were kept in one windowless poultry house with controlled environment and without access to the yard. While ducks were kept in a heated rearing house to the fourth week of age, and afterwards they were kept on yards of restricted area, partially shedded and covered with straw.

In each generation birds were fed ad libitum on complete feeds of similar chemical composition. This diet until the third week of age contained up to $20 \%$ crude protein and up to $12.13 \mathrm{MJ}$ metabolizable energy, and later up to $16.5 \%$ crude protein and 12.34 MJ metabolizable energy per $1 \mathrm{~kg}$ of feed. The mashes were of commercial origin and therefore their composition of row material slightly differed.

The mean number of eggs from one layer was calculated from laying performance records collected from January to June each year. All eggs laid during two weeks of the peak laying period were weighed. The percentage of egg fertilization and hatchability was determined each year by analysing 4 to 6 hatches conducted in walkin incubators type ATLAS S-18 (setter) and ATLAS 180 hatcher. The time trends of traits in all generations were calculated as linear regression equations. 


\section{Results}

Mean values of the reproductive traits and their variation coefficients of eight generations were compared in two periods of duck performance (Table 2). In the first year, the conservative flocks of birds demonstrated significantly differentiated egg numbers, from 101 (K2) to $156(\mathrm{Kh} 1)$; egg weights, from $70(\mathrm{~K} 2)$ to $75 \mathrm{~g}(\mathrm{Kh} 0)$ and percentages of ducklings hatched from fertilized eggs, from $62(\mathrm{Kh} 0)$ to $72 \%(\mathrm{~K} 2)$. No significant differences were found in egg fertilization and duckling hatchability from the set eggs of all experimental flocks. The ducks of K2 flock exhibited the lowest values and worst equalization of egg number, weight and fertilization.

Table 2

Mean values ( $\mathrm{x}$ ) and coefficients of variation ( $\mathrm{v} \%$ ) of reproductive traits in eight duck generations in the first (I) and second (II) year of laying performance (Mittelwerte (x) und Variationskoeffizienten (v \%) der Reproduktionsmerkmale von 4 Entengruppen im ersten (I) und zweiten (II) Jahr der Legeleistung über 8 Generationen)

\begin{tabular}{|c|c|c|c|c|c|c|c|c|c|c|c|}
\hline \multirow{3}{*}{ Flock } & & \multirow{2}{*}{\multicolumn{2}{|c|}{$\begin{array}{c}\text { Number of eggs, } \\
\text { pcs (NE) }\end{array}$}} & \multirow{2}{*}{\multicolumn{2}{|c|}{$\begin{array}{c}\text { Egg weight, } \\
\text { g (EW) }\end{array}$}} & \multirow{2}{*}{\multicolumn{2}{|c|}{$\begin{array}{l}\text { Egg fertility } \\
\%(\mathrm{EF})\end{array}$}} & \multicolumn{4}{|c|}{ Hatched ducklings in $\%$} \\
\hline & & & & & & & & \multicolumn{2}{|c|}{$\begin{array}{c}\text { from eggs set } \\
\text { (HES) }\end{array}$} & \multicolumn{2}{|c|}{$\begin{array}{l}\text { from fertile eggs } \\
\text { (HFS) }\end{array}$} \\
\hline & & $\mathrm{I}$ & II & I & II & I & II & $\mathrm{I}$ & II & I & II \\
\hline \multirow{3}{*}{ Kh1 } & $\mathrm{x}$ & $156 a$ & $144 \mathrm{a}$ & $72 b c$ & $71 \mathrm{ab}$ & $93 a$ & $90 \mathrm{~b}$ & $64 a$ & $61 \mathrm{a}$ & $69 \mathrm{ab}$ & $67 \mathrm{a}$ \\
\hline & $\mathrm{v}$ & 8.5 & 12.2 & 2.8 & 4.6 & 2.2 & 3.6 & 11.5 & 12.7 & 10.3 & 10.6 \\
\hline & $\mathrm{x}$ & $143 a$ & $126 b$ & $73 \mathrm{ab}$ & $71 \mathrm{ab}$ & $93 a$ & $92 \mathrm{ab}$ & $60 \mathrm{a}$ & $59 a$ & $65 \mathrm{ab}$ & $64 a$ \\
\hline \multirow[t]{2}{*}{01} & $\mathrm{v}$ & 10.7 & 13.4 & 3.2 & 5.9 & 3.1 & 3.2 & 18.4 & 19.5 & 17.4 & 17.7 \\
\hline & $\mathrm{x}$ & $150 \mathrm{a}$ & $145 \mathrm{a}$ & $75 a$ & $73 a$ & $94 a$ & $92 \mathrm{ab}$ & $58 \mathrm{a}$ & $61 a$ & $62 b$ & $66 a$ \\
\hline Kh0 & $\mathrm{V}$ & 12.4 & 10.5 & 2.5 & 3.9 & 1.2 & 3.1 & 14.1 & 10.8 & 13.4 & 9.4 \\
\hline \multirow[b]{2}{*}{ K2 } & $\mathrm{X}$ & $101 \mathrm{~b}$ & $98 \mathrm{c}$ & $70 \mathrm{c}$ & $69 \mathrm{~b}$ & $86 a$ & $94 a$ & $63 a$ & $66 a$ & $72 a$ & $71 \mathrm{a}$ \\
\hline & $\mathrm{V}$ & 17.2 & 17.7 & 3.5 & 5.3 & 1.8 & 1.9 & 22.2 & 9.7 & 12.3 & 9.5 \\
\hline
\end{tabular}

Mean values in columns with different letters are statistically different at $\mathrm{P} \leq 0.05$

In the second year, a decline in egg number and weight was found in all flocks of ducks whereas in the Kh1, 01, and Kh0 flocks a slight drop in egg fertilization and hatchability from set eggs was noted.

Regression equations of the reproductive traits flocks are presented in Figure 1. In the number of eggs laid over eight generations and in the first year of laying performance an upward trend was observed in the Kh1, 01 and K2 flocks, whereas a downward one in the Kh0 flock. In the egg weight and hatchability from set eggs an upward time trend was noted in all conservative flocks. On the other hand, in egg fertilization a downward trend was found in the 01 to $\mathrm{K} 2$ flocks but an upward trend in the $\mathrm{Kh} 1$ and Kh0 flocks. In all experimental flocks (except K2), the hatchability of ducklings from set eggs demonstrated an upward time trend.

In the second year of performance, the trends in the reproductive traits did not differ from those estimated in the first year, with the exception of a downward trend in egg number in $\mathrm{Kh} 1$, in egg weight in $\mathrm{K} 2$ and in hatchability from fertilized eggs in Kh0 and an upward trend in egg fertilization (01) and hatchability from the set eggs (K2). The differences in meatiness (Table 3) among flocks over eight generations and in both sexes were found in the body weight at 7 weeks of age and in breast and leg muscle yield. No statistically significant differences were found at 3 weeks of age in the body weight, and in skin with subcutaneous fat content in the carcass of 7-week old ducks of both sexes. 

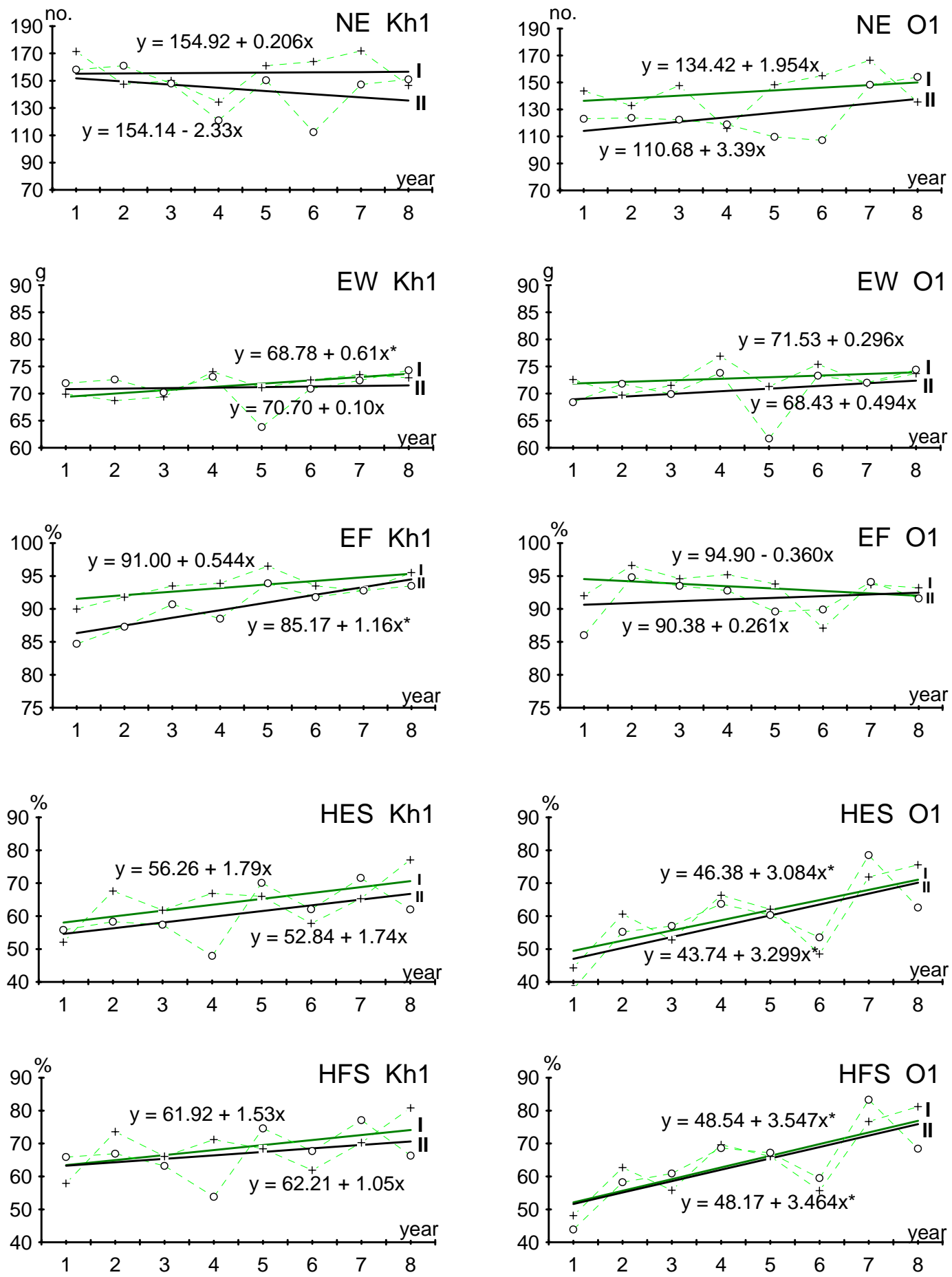

Fig. 1 a: Time trends of reproductive traits in the first (I) and second (II) year in 2 flocks of ducks over 8 generations (Zeittrends der Reproduktionsmerkmale im ersten (I) und zweiten (II) Jahr der Legeleistung in den 2 Entengruppen über 8 Generationen)

In the seventh week of age and in all flocks the males reached a higher body weight than females, contrary to that found in the third week of age. The heaviest birds of both sexes were found in the 01 flock whereas the lightest ones were Kh1 males and $\mathrm{K} 2$ females. Carcasses of $\mathrm{K} 2$ demonstrated the highest breast muscle content, $13.6 \%$ in males and $14.7 \%$ in females, and the lowest content of leg muscles $13.7 \%$ and $13.3 \%$ respectively. However, the carcasses of those ducks in both sex had the highest content of skin with subcutaneous fat (25.0 and $25.2 \%$ respectively). The lowest breast muscle 
yield $10.9 \%$ in males and $11.8 \%$ in females was found in the carcasses in the 01 flock. On the other hand, the lowest content of skin with subcutaneous fat was noted in Kh1 birds, 22.4 and $22.6 \%$ respectively in males and females.
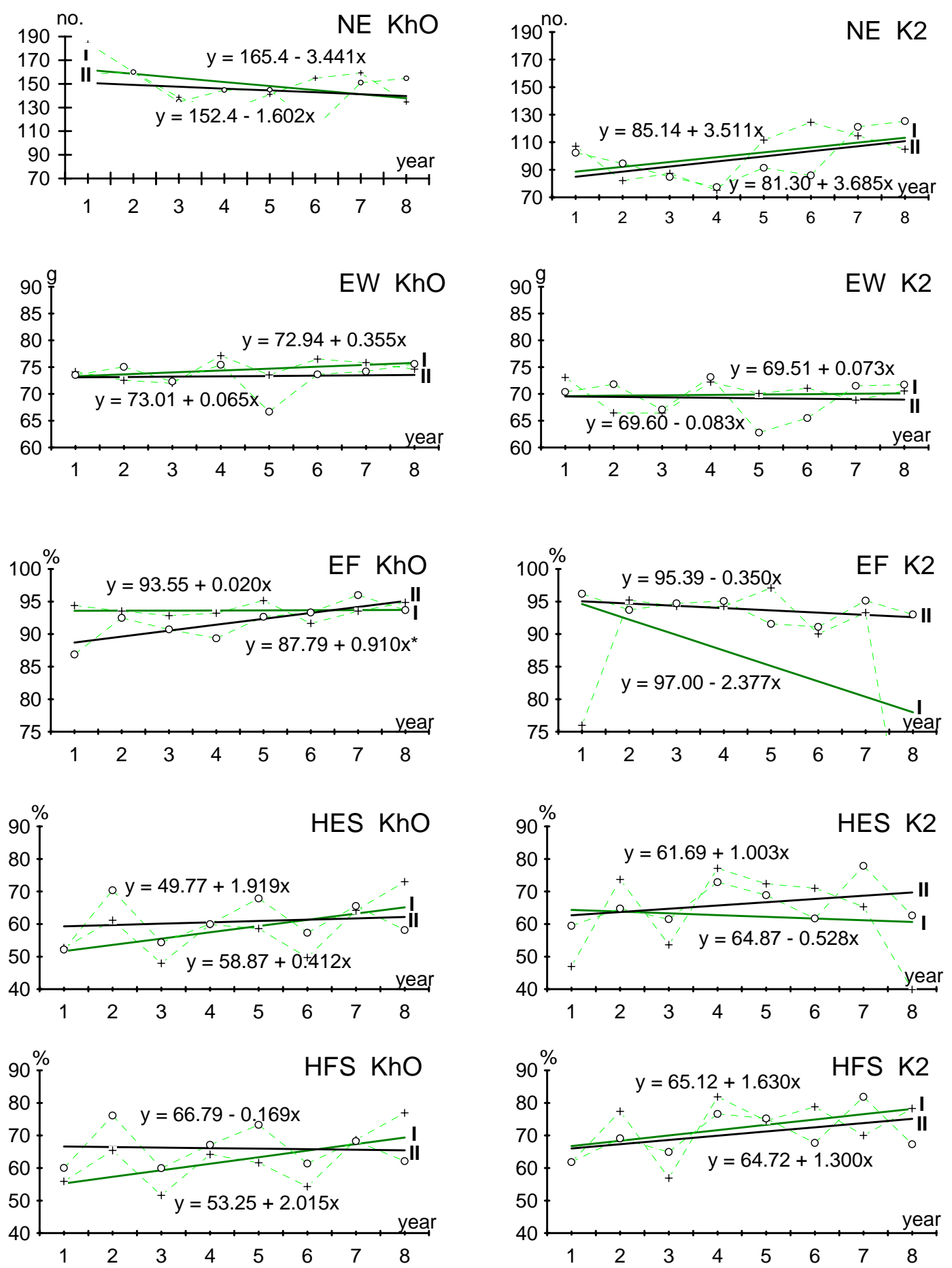

Fig. $1 \mathrm{~b}$ : Time trends of reproductive traits in the first (I) and second (II) year in 2 flocks of ducks over 8 generations (Zeittrends der Reproduktionsmerkmale im ersten (I) und zweiten (II) Jahr der Legeleistung in den 2 Entengruppen über 8 Generationen)

A large variation was estimated for the body weight of birds at 3 weeks of age, since the coefficient of variation (v) ranged from 15.9 to $26.2 \%$ and for the breast muscle content it ranged from 14.0 to $25.6 \%$. A smaller variation from 12.1 to $17.7 \%$ was estimated in the content of skin with subcutaneous fat in the carcass. 
Table 3

Mean values (x) and coefficients of variation ( $\mathrm{v} \%$ ) of meat traits in eight generations of male and female ducks from conservative flocks (Mittelwerte (x) und Variationskoeffizienten (v \%) der Fleischanteilmerkmale von Enten und Erpeln aus 4 Entengruppen über 8 Generationen)

\begin{tabular}{|c|c|c|c|c|c|c|c|c|c|c|c|}
\hline \multirow{3}{*}{ Flock } & & \multicolumn{4}{|c|}{ Body weight in g (age / sex) } & \multicolumn{6}{|c|}{ Edible parts in the eviscerated carcass in $\%$} \\
\hline & & \multicolumn{2}{|c|}{3 weeks (BW3) } & \multicolumn{2}{|c|}{7 weeks (BW7) } & \multicolumn{2}{|c|}{$\begin{array}{c}\text { breast muscles } \\
(\mathrm{BM})\end{array}$} & \multicolumn{2}{|c|}{ leg muscles (LM) } & \multicolumn{2}{|c|}{$\begin{array}{c}\text { skin with } \\
\text { subcutaneous fat } \\
(\mathrm{SSF})\end{array}$} \\
\hline & & $\hat{0}$ & 온 & $\hat{0}$ & q & $0^{1}$ & 운 & 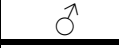 & 온 & $\hat{0}$ & 운 \\
\hline Kh1 & $\begin{array}{l}\mathrm{X} \\
\mathrm{v}\end{array}$ & $\begin{array}{c}498 \mathrm{a} \\
21.2\end{array}$ & $\begin{array}{l}507 \mathrm{a} \\
15.2\end{array}$ & $\begin{array}{c}1583 \mathrm{c} \\
8.7\end{array}$ & $\begin{array}{c}1468 b \\
5.1\end{array}$ & $\begin{array}{c}11.4 \mathrm{ab} \\
22.9\end{array}$ & $\begin{array}{c}12.5 \mathrm{ab} \\
18.2\end{array}$ & $\begin{array}{c}16.0 \mathrm{a} \\
9.8\end{array}$ & $\begin{array}{c}15.5 \mathrm{a} \\
8.0\end{array}$ & $\begin{array}{c}22.4 \mathrm{a} \\
17.3\end{array}$ & $\begin{array}{c}22.6 \mathrm{a} \\
14.2\end{array}$ \\
\hline 01 & $\begin{array}{l}X \\
v\end{array}$ & $\begin{array}{l}508 \mathrm{a} \\
26.2\end{array}$ & $\begin{array}{l}529 a \\
21.6\end{array}$ & $\begin{array}{c}1735 \mathrm{a} \\
9.2\end{array}$ & $\begin{array}{c}1651 \mathrm{a} \\
5.6\end{array}$ & $\begin{array}{l}10.9 b \\
22.2\end{array}$ & $\begin{array}{l}11.8 b \\
20.9\end{array}$ & $\begin{array}{c}15.8 \mathrm{a} \\
9.0\end{array}$ & $\begin{array}{c}15.2 \mathrm{a} \\
11.1\end{array}$ & $\begin{array}{c}22.5 \mathrm{a} \\
16.2\end{array}$ & $\begin{array}{c}23.7 \mathrm{a} \\
12.3\end{array}$ \\
\hline Kh0 & $\begin{array}{l}x \\
v\end{array}$ & $\begin{array}{l}562 \mathrm{a} \\
23.7\end{array}$ & $\begin{array}{l}570 a \\
20.5\end{array}$ & $\begin{array}{c}1708 \mathrm{ab} \\
6.2\end{array}$ & $\begin{array}{c}1613 \mathrm{a} \\
4.0\end{array}$ & $\begin{array}{c}11.4 \mathrm{ab} \\
25.6\end{array}$ & $\begin{array}{c}12.5 \mathrm{ab} \\
21.9\end{array}$ & $\begin{array}{c}15.8 \mathrm{a} \\
8.9\end{array}$ & $\begin{array}{c}15.5 \mathrm{a} \\
10.9\end{array}$ & $\begin{array}{c}24.3 \mathrm{a} \\
13.9\end{array}$ & $\begin{array}{c}22.9 \mathrm{a} \\
17.1\end{array}$ \\
\hline $\mathrm{K} 2$ & $\begin{array}{l}X \\
V\end{array}$ & $\begin{array}{l}555 \mathrm{a} \\
18.6\end{array}$ & $\begin{array}{l}573 a \\
15.9\end{array}$ & $\begin{array}{c}1599 b c \\
3.7\end{array}$ & $\begin{array}{c}1465 b \\
3.7\end{array}$ & $\begin{array}{c}13.6 \mathrm{a} \\
14.0\end{array}$ & $\begin{array}{c}14.7 \mathrm{a} \\
17.4\end{array}$ & $\begin{array}{c}13.7 \mathrm{~b} \\
11.1\end{array}$ & $\begin{array}{c}13.3 \mathrm{~b} \\
11.0\end{array}$ & $\begin{array}{c}25.0 \mathrm{a} \\
12.1\end{array}$ & $\begin{array}{c}25.2 \mathrm{a} \\
14.7\end{array}$ \\
\hline
\end{tabular}

Mean values in columns with different letters are statistically different at $\mathrm{P} \leq 0.05$

Body weights of males and females at 3 weeks of age demonstrated downward time trends in all flocks (Fig. 2). However, the body weight at 7 weeks of age showed upward trends only in the Kh1 and $\mathrm{K} 2$ females and downward trends in the females from the two other flocks and in males from all flocks.

In all conservative flocks of ducks downward trends in the percentage content of breast muscles and upward trends in the percentage content of leg muscles and of skin with subcutaneous fat in the carcass were found over eight generations.

\section{Discussion}

Khaki Campbell ducks created by crossing Rouen male with Malaysian Indian Runner female are included among the four main laying breeds of that poultry species (SCOTT and DEAN, 1991). They lay 184 eggs up to the 76th week on average (HETZEL and GUNAWAN, 1984) or even 229 eggs up to the $68^{\text {th }}$ week (HETZEL, 1984). The magnitude of egg production in ducks is dependent on the extensive or intensive management system including battery cages, as well as on nutrition programme (AVENS et al.; 1980; FARRELL, 1995; HETZEL, 1984; HETZEL and GUNAWAN, 1984; SCOTT and DEAN, 1991). The number of 156 eggs laid on average over 8 generations in six month periods can be considered high. The laying type of Khaki Campbell duck is evidenced by its early sexual maturity being reached already at the age of 18 weeks (KLANDORF and HARVEY, 1984); 20 weeks (HETZEL and GUNAWAN, 1984) or 23 weeks (ESWARAN et al., 1984). That breed has been used in crossing with indigenous varieties of Indonesian, Chinese and Indian ducks for increasing table egg production (FARRELL, 1995; HETZEL and GUNAWAN, 1984; YANG and WU, 1988). In KhO birds, created by crossing of Kh1 with 01 birds the number of eggs has increased by 7 on average compared with Orpington ducks. 

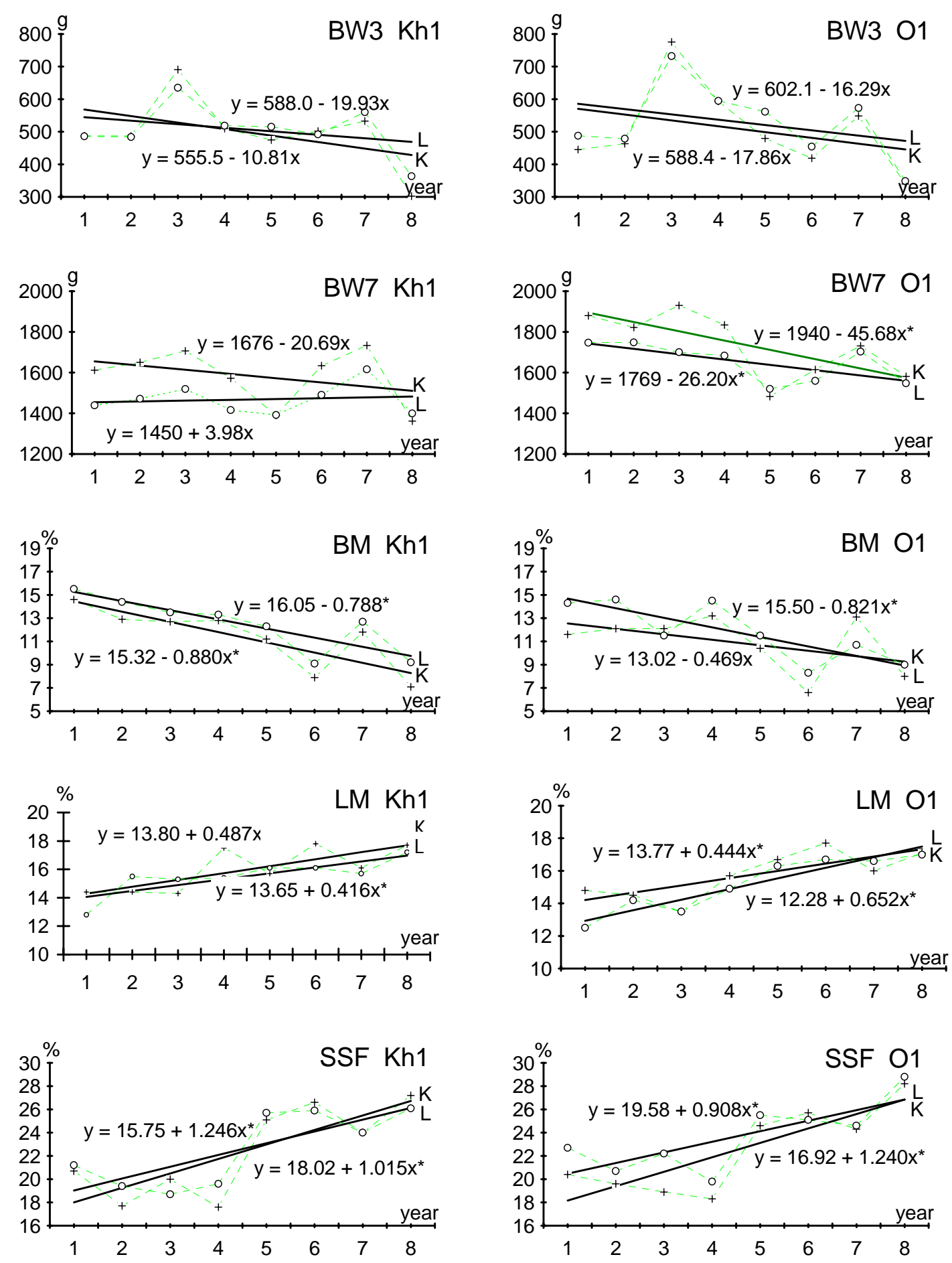

Fig 2 a: Time trends of meat traits in the male $(\mathrm{K})$ and female (L) ducks from 2 flocks of ducks over 8 generations (Zeittrends der Mastmerkmale für die Erpel $(K)$ und die Enten $(L)$ in den 2 Entengruppen über 8 generationen

The lowest average number of eggs was noted in $\mathrm{K} 2$ ducks, created using the wild duck Anas platyrhynchos $L$. The low number of eggs laid by birds created with the contribution of that duck species was by STAŠKO (1980). Both in the first and second period of performance, the $\mathrm{K} 2$ flock showed the highest coefficient of variation in the number of eggs (17.2 to $17.7 \%)$. In the second year a decline in the total number of eggs was noted in all duck flocks, and that finding confirmed the results reported 
earlier by KSIAZŻKIEWICZ (1996). In Kh1 flock the decline reached 7.7\%, was highest $(11.9 \%)$ in 01 flock and similar in $\mathrm{Kh} 0$ and $\mathrm{K} 2$ flocks ranging from 3.0 to $3.4 \%$.
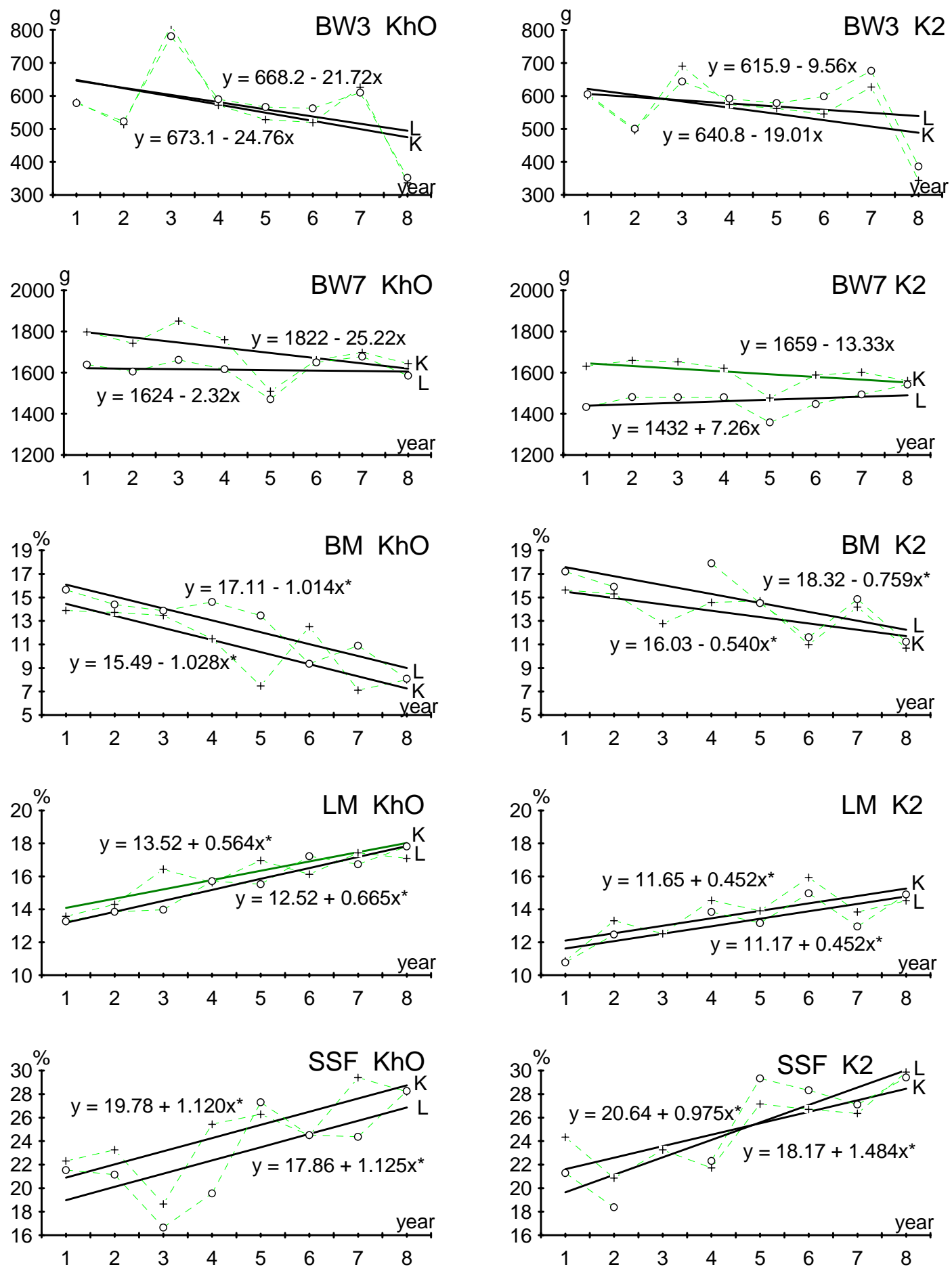

Fig $2 \mathrm{~b}$ : Time trends of meat traits in the male $(\mathrm{K})$ and female $(\mathrm{L})$ ducks from 2 flocks of ducks over 8 generations (Zeittrends der Mastmerkmale für die Erpel (K) und die Enten (L) in den 2 Entengruppen über 8 Generationen)

The results of egg weight were comparable with the earlier weight assessments carried out on six duck generations by KSIĄŻKIEWICZ (1996). The mean egg weight in Kh1 
flock was $8.6 \mathrm{~g}$ higher than that reported by HETZEL (1984) and $1.4 \mathrm{~g}$ lower than that found by SCOTT and DEAN (1991). A narrow range of egg weight variation coefficients from 2.5 to $5.9 \%$ was noted between flocks. In the second year, in all flocks of ducks lighter eggs by $1.4 \%$ (Kh1 and K2) or by $2.7 \%$ (01 and Kh0) than in the first year were laid.

Egg fertilization in Kh1 ducks was found to be $16.2 \%$ higher and hatchability from fertilized eggs 3.4\% lower than that reported by NARAHARI et al. (1991). These authors demonstrated that egg fertilization and duckling hatchability were higher in ducks kept on free range with access to water than in those kept on deep litter without any access to ponds. They also observed a linear growth of egg fertilization in Khaki Campbell from 74.8 to $81.8 \%$ (accompanied by an increase of mean egg weight from $60.0 \mathrm{~g}$ to $74.9 \mathrm{~g}$ ) and a decline in egg fertilization from 82.3 to $74.7 \%$ with the extension of egg storage time from 1 to 9 days.

As reported earlier by KSIĄŻKIEWICZ and MAZANOWSKI (1984), poorer hatchability than that presented in Table 2 was noted in all conservative flocks of ducks due to less efficient incubators. Because the setters and hatchers were of different construction, and incubation conditions, housing of parent stock and handling of hatching eggs prior to incubation were different, the data on duckling hatchability are very difficult to compare. Diminishing egg fertilization in the second year of laying utilization in Kh1, 01 and Kh0 flocks as well as of hatchability from the eggs set (Kh1, 01) and fertilized eggs (Kh1, 01, K2) reported earlier by KSIĄŻKIEWICZ (1996) were found to be of biological nature.

In the studied flocks, the birds of both sexes demonstrated similar meatiness, compared with 7-week-old ducks used in the earlier studies by KSIĄŻKIEWICZ (1995). That was affected, among others, by the high heritability of the examined traits (PINGEL, 1990) and by comparable environmental and feeding conditions. Lower body weight in $\mathrm{Kh} 1$ and $\mathrm{K} 2$ than in 01 and $\mathrm{Kh} 0$ ducks, accompanied by the highest percentage content of breast muscles in $\mathrm{K} 2$ and of thigh and drumstick muscles in K1 ducks, reported earlier by KSIAZŻKIEWICZ (1997), were confirmed in this study. The ducks from the conservative flocks demonstrated lower body weight in the third and seventh week of age than those of the Pekin type studied by HUDSKÝ et al. (1973) and RIZK (1975). This study indicated that ducks of the conservative flocks were less fat than those of Pekin type.

Other authors (HETZEL and SIMMONS, 1983; HUDSKÝ and ČERVENY, 1973; STAŠKO, 1990) also examined live body weight, breast and leg muscles and skin with subcutaneous fat content in the carcass of various types of the duck and found great differentiation of the studied traits.

Mean body weight in the 7-week-old Kh1 ducks was close to that found in the same breed but in different environmental and feeding conditions (HETZEL, 1984; HETZEL and SIMMONS, 1983; HUDSKÝ et al. 1973). On the other hand, the mean body weight in the Orpington duck noted in this study was lower than that reported by BAUMGARTNER et al. (1992).

My findings concerning meatiness in Miniducks confirm those published by STAŠKO (1980) that ducks bred with the contribution of the wild duck Anas platyrhynchos $L$. are well fleshed and demonstrate higher percentage breast muscle content than Pekin type ducks. 
A high variation of body weight in the third week of age and of the percentage breast muscle yield in the 7-week-old duck was noted in earlier studies (KSIAZŻKIEWICZ et al., 1997). The coefficients of variation for the other meatiness traits were not different from those reported previously by KSIAZŻKIEWICZ and MAZANOWSKI (1984) and KSIĄŻKIEWICZ, (1997).

PINGEL reported (1990) that heritability $\left(\mathrm{h}^{2}\right)$ values of the reproductive traits in the duck found by various authors were as follows: number of eggs 0.17 to 0.42 ; egg weight 0.23 to 0.60 ; egg fertilization 0.01 to 0.52 ; hatchability 0.14 to 0.42 . On the other hand, the heritability of the body weight until 7 to 8 weeks of age ranged from 0.28 to 0.76 and in the meatiness traits there were medium and high heritability values. In the case of reproductive traits, heritability effect on the total variation is lower than that in meatiness traits. Hence the major effect of the environment on the studied reproductive traits might, in most cases, influence their upward time trend. In the conservative poultry populations of limited number and with random selection, individuals having better reproductive ability can be preferred. The existing antagonism between reproductive and meatiness could worsen the meatiness trait. The upward time trends in hatchability can be attributed to long-term application of improved desinfection methods and to proper way of handling hatching eggs prior to setting.

The downward time trends in the body weight and percentage content of breast muscles in the carcass are regarded as unfavourable. They may result, among others, from the inbreeding of particular duck population as well as from the occurrence of the genetic drift. The downward time trend of egg fertilization in the 01 flock over the first year, and in the K2 flock over the first and second year of study, could be attributed to the increasing early embryonic mortality.

The parent groups of ducks could not be completed in a representative way, i.e. by substituting the male by the son and the female by the daughter, because the studied birds were kept in groups.

From the studies by PINGEL (1990) and STAŠKO (1980) it can be seen that the values of the genetic correlation coefficients between percentage yield of breast muscles and of leg muscles in the carcass are negative. PINGEL (1990) reported that selection for increasing body weight and breast muscle thickness carried out over 7 generations of ducks resulted in higher breast muscle yield by $9.4 \%$ and lower leg muscle yield by $-1.5 \%$, due to the negative genetic correlation between those groups of muscles. On the other hand, the decline of the percentage content of breast muscles caused an increase of the percentage content of leg muscles in the carcass (Fig. 2) also due to the existing negative correlation.

The Kh1, 01, Kh0 and K2 conservative flocks of ducks demonstrated considerable differences in some reproductive and meatiness traits. The particular advantage of those populations compared with the Pekin type ducks, was the lower content of skin with subcutaneous fat content and of blood lipids, such as cholesterol and triglicerides, as reported by KSIAZŻKIEWICZ et al. (1997). Those flocks may be used in breeding work on ducks in the future.

\section{Conclusions}

In the first year of study by 8 generations a significant differentiation was noted between flocks in: number of eggs, from $101(\mathrm{~K} 2)$ to $156(\mathrm{Kh} 1)$; egg weight, from 70 
$(\mathrm{K} 2)$ to $75 \mathrm{~g}(\mathrm{Kh} 0)$ and hatchability from fertilized eggs, from $62(\mathrm{Kh} 0)$ to $72 \%(\mathrm{~K} 2)$. In the second year of study a lower egg number and egg weight were found, as well as lower egg fertilization and hatchability. In the first year, upward time trends in egg weight and hatchability from fertilized eggs were noted in all flocks of birds, whereas in egg number in Kh1, 01 and K2 flock; and in egg fertilization in Kh1 and Kh0 flocks. Differentiation in meatiness mean values between duck flocks was found over 8 generations of both sexes in body weight at 7 weeks of age and in breast and leg muscle yield in the carcass. Upward time trends in leg muscle yield and skin with subcutaneous fat content in the carcass were noted in all flocks of ducks of both sexes while in body weight at 7 weeks of age in the females of Kh1 and K2 flocks. Contrary, downward time trends in the body weight at 3 . week of age and in breast muscle yield at 7. week of age were found in birds of both sexes and all conservative flocks.

\section{References}

AVENS, J.S.; ATHEARN, R.M.; MC NEAL, J.H.:

Egg production and efficiency of food conversion of Khaki Campbell ducks under different management systems. Br. Poultry Sci., 21 (1980), 333-337

BAUMGARTNER, J.; MIČEK, L.; LEDEČ, M.; BENKOVÁ, J.; SOUKUPOVÁ, Z.:

Conservation of genetic resources and application in breeding of poultry (in Czech). Sbornik Akademie Zemédelských Véd 159 (1992), 53-69

ESWARAN, K.R.; RAMAKRISHNAN, A.; VENVGOPALAN, C.K.; NAIR, G.R.:

Comparative performance of Khaki Campbell and Desi duck. Indian J. Poultry Sci. 19 (1984), 70-73

FARRELL, D.J.:

Table Egg Laying Ducks: Nutritional Requirements and Current Husbandry Systems in Asia. Poultry and Avian Biology Reviews 6 (1995), 55-69

HETZEL, D. J. S.:

Comparative performance of intensively managed Khaki Campbell and native Indonesian duck. Tropical Animal Health and Production 16 (1984), 39-45

HETZEL, D. J. S.; GUNAWAN, B.:

Egg production of Indonesian native and crossbred under intensive and extensive conditions. Tropical Animal Production 9 (1984), 203-215

HETZEL, D. J. S.; SIMMONS, G. S.:

Growth and carcass characteristics of Alabio, Bali, Tegal and Khaki Campbell drakes on a high plane of nutrition. Sabrao J. 15 (1983), 117-123

HUDSKÝ, Z.; ČERVENY J.:

Analysis of ducks from meat types (in Czech). Živ. Vyr. 28 (1973), 235-240

HUDSKÝ, Z.; LAUTNER, V.; BLAŽEK, J.:;

Meat traits of ducks from different types (in Czech). Živ. Vyr. 18 (1973), 65-70

KLANDORF, H.; HARVEY, S.:

Changes in thyroid function and gonadotropin activity during sexual development in duck. Journal of Zoology 203 (1984), 103-112

KSIĄŻKIEWICZ, J.:

Duck gene pool. Proc. Intern. Symp. on Conservation Measures for Rare Farm Animal Breeds, Balice -Poland (1995), 289-292

KSIĄŻKIEWICZ, J.:

The effect of origin and two years of utilization on certain performance traits of ducks from four preserve groups (in Polish). Pr. Mat. Zoot. 49 (1996), 109-118

KSIĄŻKIEWICZ, J.:

Characteristics of meatness traits in six generations of ducks in conservative groups. J. Anim. Feed Sci. 6 (1997), 101-108

KSIĄŻKIEWICZ, J.:

Reproductive and meat characteristics of Polish ducks threatened with extinction. Czech J. Anim. Sci. 47 (2002), 401-410

KSIĄŻKIEWICZ, J.; MAZANOWSKI, A.:

A characteristics of reproductive traits of ducks from conservative groups (in Polish). Zeszyty Naukowe Drobiarstwa 1 (1984), 17-27 
KSIĄŻKIEWICZ, J.; PRUSZYŃSKA, E.; ŚWITALSKI, M.:

Differentiation of duck conservative groups under some morphological characteristics. Proc. 11th European Symposium on Waterfowl, Nantes -France (1997), 320-326

NARAHARI, D.; MUJEER, K. A.; AHMED, M.; RAJINI, R. A.; SUNDARARASU, V.:

PINGEL H.: Factors influencing the hatching performance of ducks eggs. Br. Poultry Sci. 32 (1991), 313-318

Genetics of egg production and reproduction in waterfowl. Poultry Breeding and Genetics - R.D. CRAWFORD, Ed (1990), pp. $771-780$

RIZK, M. A.:

Vergleichende Untersuchungen über Mast- und Ausschlachtungsleistungen sowie Fleisch Qualitätsmerkmale bei verschiedenen Geflügelarten und -herkünften. Univ. Bonn, Dr. thesis, 1975

SCOTT, M. L.; DEAN, W. F.:

STAŠKO, J:

Nutrition and management of ducks - M.L.Scott Ed, Ithaca (1991), 1-177

To the problem of small broiler duck. Proc. Intern. Conf. on Breeding and Geese Production, Koluda Poland (1980), 219-227

WORLD WATCH LIST FOR DOMESTIC ANIMAL DIVERSITY:

WRIGHT, S.:

FAO, UNDP, $3^{\text {rd }}$ edition (2000), 3-73, 351

YANG, C.; WU, K.:

Breed resources and conservation measures in Chinese indigenous waterfowl. Proc. 18th Poultry Congress, Intern. Symp. on Waterfowl Production, Beijing -China (1988), 113-118

Received: 2002-12-16

Accepted: 2003-06-12

Authors address

Prof. Dr. JULIUSZ KSIAZŻKIEWICZ

Department of Waterfowl Breeding Dworzyska,

National Research Institute of Animal Production,

62-035 Kórnik near Poznan, Poland

E-Mail: ksiaz@poczta.onet.pl 